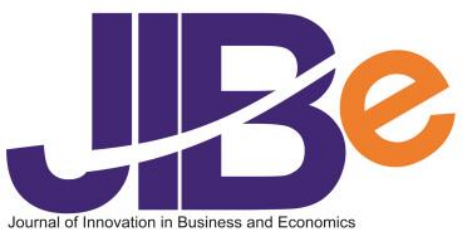

\title{
Empowerment of former migrant workers: Triple bottom line framework
} Sri Wahjuni Latifah ${ }^{1}$, Agung Riyardi ${ }^{2}$

\author{
Accounting Department, Faculty of Economics and Business, \\ Universitas Muhammadiyah Malang, Indonesia ${ }^{1}$ \\ Economic Department, Faculty of Economics and Business, \\ Universitas Muhammadiyah Surakarta, Indonesia ${ }^{2}$
}

\begin{abstract}
This study aims to analyze the empowerment of former Indonesian migrant workers, especially in the potential of running small businesses. The research data were collected by interview and literature study and the data were classified and analyzed using SWOT analysis. The SWOT analysis results are interpreted with a triple bottom line framework approach, which includes financing, environment, and social. The results of the study show that the migrant workers in Donomulyo district have sufficiently good capital in terms of financing, environment, especially in natural resources, and the social environment that allows business growth. One of the main challenges is human resources, ranging from entrepreneurial spirit to minimal managerial skills. Therefore, stakeholders must focus on programs that prioritize improving entrepreneurial skills and managerial aspects.
\end{abstract}

Keywords: Indonesian former migrant worker; small business; triple bottom line

\section{Introduction}

Indonesian former migrant workers are migrant workers who have returned to Indonesia who does not continue their activities working abroad. Pîrvu \& Axinte (2012) argue that a former migrant worker is a final part of the work cycle abroad that reaches 10 to 20 years. After several times working abroad, the Indonesian former migrant worker decided to settle in his home country. One of the main reason the migrant workers to stop and back is based on a comparison between the benefits gained and the costs borne from working abroad (Rizal \& Mustapita, 2017). Decisions are also influenced by education factor, gender, age, economic, and family, such as the retirement was taken after considering family which could not be a moved abroad, or savings for family life which have been fulfilled (Vadean \& Piracha, 2009).

The number of Indonesian migrant worker who goes abroad always increasing in consecutive years. The problem is experienced by the Indonesian former migrant workers that they become unemployed. They also do not have enough preparation for doing business, especially if they pay attention to their negative characteristics. The fact is: almost $70 \%$ of Indonesian Migrant Workers are graduated from primary school; there are even cases that are found illiterate. Besides, the fact is that the income of Former Indonesian Labor is embedded in unproductive assets such as land, houses, and vehicles. It is even possible that their remittances cause inflation and the quality of life of local society does not increase (Haryati, 2009).

Doing business is one of the solutions for former migrant workers. Entrepreneurship becomes a solution because they already have assets in land, buildings, vehicles, or savings. They also have the experience of living and working abroad in favor of becoming a first-time entrepreneur. They also have full connectivity of the fellow Indonesian former migrant worker that is useful for various information, knowledge, and experience of business activities (Hidayat, 2009). However, there is no clarity about the business that the Indonesian former migrant worker must occupy. Even if there is, it is not known how an Indonesian former migrant worker chooses a business.

Gubert \& Nordman (2008) analyze that the most international workforce in Algeria, Morocco, and Tunisia have many entrepreneurial trades, hotels and restaurants, commerce, industry and construction. However, it is not explained how the process of choosing the business. Hakim (2011) describes some of the former women migrant worker economic strategies that include subsistence production and additional income. Meanwhile, Busro (2018) discusses the importance of training and providing capital for Indonesian former migrant workers who want to do entrepreneurship. However, it is not clear what most migrant workers choose in business. Therefore, we analyze the right business for Indonesian former migrant

\footnotetext{
${ }^{1}$ E-mail: sriwahjuni@umm.ac.id
} 
workers using the Triple Bottom line approach. It is hoped that through this case it will be obtained business model for Indonesian former migrant workers.

This brief study is expected to answer an Indonesian former migrant worker model that seeks sustainably based on the Triple Bottom Line approach. There are three research objectives: first, analyzing the Indonesian former migrant workers criteria in generating economic value; second, analyzing Indonesian former migrant workers to use natural resources; and third, analyzing Indonesian former migrant workers in communicating with the surrounding economic community. With the Triple Bottom Line approach, it is expected that Indonesian former migrant workers will not be unemployed and their welfare will increase.

\section{Literature Review}

The Triple Bottom Line was developed by John Elkington, which is an accounting framework. This approach assumes that a company's success is not only measured by the profit gained but also must be measured from the environment and social side. The framework can identify Successful businesses from the bottom of financial statements that include profit, the fulfilment of environmental and social responsibilities. That is called a successful business in the 21st century (Żak, 2015).

The discussion of the Triple Bottom line in the science of sustainable development economics is minimal. Theory and reality are less widely discussed. There are three reasons behind it. First, the introduction and definition are less vigorous. Secondly, the research is lacking. The implications for developing the economic science of sustainable development and community development are less emphasized (Hammer \& Pivo, 2016). Tuazon et.al., (2013) argue that the Triple Bottom Line discussion in Sustainable Development Economics provides three contributions: first, contributed to the thought that the population as an economic problem as first put forward by Thomas Robert Malthus; second, the contribution to the development of classification under sustainability is the impact of economic value, environmental stewardship and social responsibility; third, the contribution to capital types in the economy such as natural capital, social capital, human capital, manufacturing capital and financial capital.

Based on the Hammer \& Pivo (2016); Tuazon et.al., (2013); and Żak (2015) this study uses the Triple Bottom Line approach to study how various parties participate in making Indonesian postmigrant workers become entrepreneurs, so that unemployed of Indonesian postmigrant workers problems and their welfare have been resolved. The various parties are Indonesian former migrant workers who are trying to utilize the natural resources in their surrounding environment. In addition, the government and local stakeholders are responsible for empowerment (empowering), a series of activities in expanding access to change and able to determine their own destiny, through the creation of opportunities, through the creation of business opportunities and opportunities towards the halal industry so that it is useful for stakeholders to make halal industry planning in areas with potential resources from former migrant workers.

\section{Research Method}

This study was conducted in Sumberoto Village, Purworejo, and Tempursari of Donomulyo Districts, Malang Regency of East Java Province. The selection of this location is due to the Malang regency is one of the regency in East Java that send a big enough Indonesian migrant worker. In 2015, Malang Regency sent 3033 Indonesian Migrant Workers. This research is a qualitative descriptive study with data collection using two stages: first, primary data collection through a Focused Discussion Group (FGD) and in-depth interviews involving the participation of former migrant workers and related parties. Focus Group Discussion (FGD) with the informan involving: three chiefs of Village, two informan from Cooperative Management of Donomulyo District(KUD), two informan from UKM, and thitry eight form former Indonesian migrant workers. Second, the collection of secondary data from government related documents such as statistical reports, newspapers, etc. The collected data is then classified into a SWOT matrix to analyze the strengths, weaknesses, opportunities and challenges for former migrant workers to start a business.

Furthermore, the results of the SWOT matrix are interpreted with a triple bottom line framework. Data processing is done through the cluster matrix technique. This technique is expected to show the determination of domains that affect business in the Donomulyo District. Information and data that have been obtained through the data collection stage are sorted in a table and classified into four clusters: strength, weakness, opportunity and threat (SWOT) Thompson et.al., (2012). Furthermore, the SWOT matrix results are analyzed through a triple bottom line framework, which includes financing, environment, and social. The analysis technique uses explanatory and descriptive techniques Yin (2002). 


\section{Result and Discussion Financial Aspects}

Indonesian former migrant workers in the Donomulyo District of Malang Regency have economic, social, and cultural characteristics, which indicate that they can generate economic value. Their economic characteristic is having an investment of Rp 50 million to Rp 100 million in money, gardens, land, houses or vehicles. This investment is sourced from the income they received from Rp 3 to Rp 5 million per month. The majority of Indonesian former migrant workers, $56.3 \%$, have senior high school education level. Likewise, most of them, $79.2 \%$, have farming skills. The social characteristics of Indonesian former migrant workers also indicate that they can generate economic value.

The demographic characteristics of the Indonesian former migrant workers are also characteristic of the economic. They are at a productive age with an average age of 35.28 years old, where $39.6 \%$ of them are over 40 years old, and $60.4 \%$ are between 25 to 40 years old. They also have extensive work experience. They have worked overseas, like in Taiwan. Some have worked in Hong Kong, South Korea, and Saudi Arabia. It is also an indication that they have extensive work experience.

Related to the data obtained in the financial aspect, the characteristics of Indonesian former migrant workers in Donomulyo District indicate that they can generate economic value. Even the existing internal and external communities are the potential to become social capital. If social capital is realized, it will be one of the main factors of Indonesian former migrant workers' business development in the form of clusters. This is as happens in the cluster of footwear SMEs in the city of Bogor that developed through social capital development. (Widyastutik \& Intan, 2010)

\section{Environment Aspect}

Natural resources of the Donomulyo District of Malang Regency support former migrant workers in producing economic value. According to the interviews with the Indonesian former migrant workers, FGD participants and documentation owned by the head of economic affairs of each village. The analysis of the Cluster Matrix shows the domains affecting the development of Indonesian former migrants workers business related to natural resources. The sectoral potential, there is in agriculture, plantation, animal husbandry, small industry and trade. Agriculture has superior commodities: rice and corn; plantations have superior commodities: coconut, bamboo, sugar cane, and cassava; Livestock has excellent commodity in the form of chicken and beef cattle farm. Small industries have excellent commodities in the form of snacks, household goods and kitchens, and souvenirs. Mainstream snack commodities include chips, cassava, cassava chips, cassava fermentation, dragon fruit chips, corn chips, banana chips, chips banjo and yoghurt drinks. The leading commodity of the kitchenware and household appliances industry is coconut and bamboo. Souvenirs superior commodities include souvenirs typical Donomulyo. Trade has a superior commodity in a trade that fulfils local distribution and trade to support coastal and cave tourism in South Malang.

The location of Donomulyo district is located in the southern part of the island of Java, causing coast and cave tourism to be a strength and opportunity to grow rapidly. However, SWOT analysis also shows that there is a threat from there. Natural disasters such as heavy rain, tornadoes, floods and tsunamis can cause natural damage and loss. The SWOT analysis shows that the strength of natural resources in Donomulyo District is the agriculture and plantation sector (see appendix table: 1). Other strengths are all sectors that support coastal tourism in the South Malang region. If using careful consideration, then the threats can be minimized and maximalized strength. Some things to consider in managing natural resources are: optimal natural resource extraction; natural resource prices; production development patterns; inventory influences; supervised planners management; managed by perfect competitors or monopolists; the uncertainty of natural resource extraction, the volatility of Natural Resources prices, exploration, distribution and equity (Suparmoko, 1999). The SWOT analysis shows that access to financing from financial institutions becomes a threat to the development of businesses conducted by Indonesian farmer migrant workers (see appendix table: 4) The threat comes from too small funding where the cooperative only lends IDR 1.000.000-1.500.000. Threats also come from failure to repay an overly expensive rate.

The SWOT analysis shows that the appropriate technology infrastructure becomes a weakness because it is straightforward (see appendix table: 2). Simultaneously, the SWOT analysis of information technology shows the opportunity to get access to cheaper raw materials from other places and opportunities to develop the distribution and marketing channels of all commodities to the regional, national, and international levels (see appendix table: 3). Besides, the availability of workers from former migrants workers will support this business development's success because they already have the good skills and knowledge. Although human resources have low education and motivation, the business development in the Donomulyo region will work well with the local government's support, the availability of natural 
resources and capital resources. According to the findings of Yahya \& Goh (2002), how to manage human resources is to conduct knowledge management. Training will affect the level of creativity of the workforce, including group training. Leadership skills are also indispensable, e.g. for middle-level managers or decision-making capabilities, and a direct performance appraisal system.

\section{Social Aspect}

The community in the Donomulyo District which is located in Malang Regency is very supportive of the former migrant's workers. The village government always coordinate with higher government, such as Regency, to manage former migrant workers for developing sustainable business Therefore, the Donomulyo District administration and the village administration support a group of businesses that is managed by former migrant workers. Development focus on agriculture, livestock, food, beverage, and handicraft production. The SWOT analysis shows that government support is included in the strength for the Indonesian former migrant workers (appendix table: 1). The government provides various facilities, services and facilities for Indonesian post Migrants workers. During using it, the Indonesian postmigrant worker business will flourish. Cooperatives in Donomulyo District also support Indonesian post Migrants workers to do entrepreneurship. In general, cooperative support is provided for financing, especially for business Indonesian former migrant worker.

SMEs community in Donomulyo District also support Indonesian former migrant workers. As an individual or group business organization that was founded with the aim of increasing profit, they welcomed every increase of SMEs, including those conducted by former migrant workers. More SMEs, more SMEs products are becoming more specific and different. This causes the consumer interest is met. Various studies have discussed it. An example is Salehe et.al., (2014) research, that consumers prefer specific and different fish products. It also causes the potential to win the competition due to product diversification and value-added development as found by Alonse (2011). Small and Medium Enterprises also tried to grow. The first is to consider the Natural Resources factor that is believed to be the wealth of the region which, if developed, leads to value-added for the society's income because it does not sell raw materials but goods have been processed further so that it has a higher use-value. The second is to consider the skill factor of Human Resources. Agricultural, livestock, trade and service skills are enhanced through various training on management that strengthens the character of SMEs and accelerates the achievement of goals. The third is to consider the management factor. Marketing and financial management are developed by information based on information and communications technology (ICT).

The results of this study indicate that former migrant workers in Donomulyo District, from a triple bottom line perspective, have a supportive ecosystem. Financially, they generally have savings or assets that can become capital to start a business; from an environmental perspective, raw materials are available and have high marketing potential because there are many potential beach tourisms. Meanwhile, from the social aspect, the UMKM community is also relatively conducive and supports so that former migrant workers also become new

\section{Conclusions, suggestions and limitations}

This study shows that the triple bottom line framework that refers to the SWOT analysis shows that the three main aspects, including financing, environment, and society, support former migrant workers in running a business. This study's findings reveal that the main obstacle lies in the human resources of former migrant workers, starting from the lack of entrepreneurial spirit to managerial skills. Therefore, stakeholders should direct empowerment programs for former migrant workers in the integrated aspects of entrepreneurship training, from product design to marketing. These entrepreneurial programs are to capture potential funding, environment and social support. If this program is successful, not only former migrant workers that feel the impact but also build the local economy by creating sustainable employment opportunities.

\section{Acknowledgement}

This work was partially supported by the Ministry of Research, Technology \& Higher Education of the Republic of Indonesia under Grant No: 015/SP2H/P/K7/KM/2015, Any opinions, findings, and conclusions or recommendations expressed in this material are those of the authors and do not necessarily reflect the views of the Ministry of Research, Technology \& Higher Education of the Republic of Indonesia.

\section{References}

Alhaddi, H. (2015). Tripple Bottom Line and Sustainable: A Literature Review. Business and Management Studies, 1(2), 6-10. doi:10.11114/bms.v1i2.752 
Busro, M. (2018). Strategy Increasing Entrepreneurship Interest to Post Migran Workers Through Training anf Giving of Capital. International Research Journal of Business Studies, 10(3), 147-158. doi:10.21632/irjbs

Calace, D. (2014). Non-Financial Reporting in Italian SMEs: An Explanatory Study on Strategic and Cultural Motivation. International Journal of Business Administration, 5(3), 34-48. doi:10.5430/ijba.v5n3p34

Dustmann, C., \& Weiss, Y. (2007). Return Migration: Theory and Empirical Evidence from the UK. British Journal of Industrial Relations, 45(2), 236-256.

Gubert, F., \& Nordman, C. J. (2008). Return Migration and Small Enterprise Development in Maghrib. Paris: IRD.

Hakim, A. (2011). Strategi Kelangsungan Hidup Perempuan Mantan Buruh Migran (Studi Kasus Mantan Buruh Migran Kaliwedi Kabupaten Cirebon). Widyariset, 14(1), 257-265.

Hammer, J., \& Pivo, G. (2016). The Triple Bottom Line and Sustainable Economic Development theory and Practice. Economic Development Quarterly, 1-12. doi:10.1177/0891242416674808

Haryati, E. (2009). Remitansi Tenaga Kerja Indonesia: Dampaknya terhadap Inflasi dan Kontribusinya terhadap Peningkatan Kualitas Hidup Masyarakat. Ekuitas, 13(3), 388-405.

Hidayat, D. R. (2009). Pencegahan TKI Kembali ke Luar Negeri Melalui Pelatihan untuk Dapat Berwirausaha. Jurnal Sarwahita, 13(1), 34-39. doi:10.21009/sarwahita.131.06

Jackson, A., Boswell, K., \& Davis, D. (2011). Sustainability and Triple Bottom Line Reporting--What is It all About? International Business, Humanities and Technology, 1(3), 55-59.

Kotler, P., \& Kelle, K. L. (2006). Marketing Management (12 ed.). New York, US: Prentice Hall.

Ali, M. H., \& Norhidayah Suleiman. (2016). Sustainable Food Production: Insights of Malaysian Halal Small and Medium Sized Rnterprises. Intern. Journal of Production Economics, 1-48.

Alonse, A. D. (2011). Muscadines, wineries and Value added products: An exploratory study. British Journal, 113(3).

Busro, M. (2018). Strategy Increasing Entrepreneurship Interest to Post Migran Workers Through Training anf Giving of Capital. International Research Journal of Business Studies, 10(3), 147-158. https://doi.org/10.21632/irjbs

DeKrey, S. J., \& Portugal, E. J. (2014). Strategic Sensemaking: Challenges Faced by a New Leader of an SME. Procedia - Social and Behavioral Sciences, 150, 56-65. https://doi.org/10.1016/j.sbspro.2014.09.007

Gubert, F., \& Nordman, C. J. (2008). Return Migration and Small Enterprise Development in Maghrib. Paris IRD.

Hakim, A. (2011). Strategi Kelangsungan Hidup Perempuan Mantan Buruh Migran (Studi Kasus Mantan Buruh Migran Kaliwedi Kabupaten Cirebon). Widyariset, 14(1), 257-265.

Haryati, E. (2009). Remitansi Tenaga Kerja Indonesia: Dampaknya terhadap Inflasi dan Kontribusinya terhadap Peningkatan Kualitas Hidup Masyarakat. Ekuitas, 13(3), 388-405.

Jauhari, J. (2010). Upaya Pengembangan UKM dengan Memanfaatkan Ecomerce. Jurnal Sistem Informasi, 2(1).

Kotler, P., \& Kelle, K. L. (2006). Marketing Management (12 ed.). Prentice Hall.

Kristia. (2019). Model Bisnis Trplle Bottom Line Pasar Komunitas Makanan Sehat dan Pengembangannya dalam Mewujudkan Rantai Pasok Pangan Berkelanjutan. Jurnal Manajemen dan Kewirausahaan, 7(2), 139-153.

Kristiyana, N., \& Hamidah, C. (2014). Transisi Peran TKI Purna di Ponorogo, dari Buruh menjadi Wirausahawan dan Tuan Tanah. Jurnal Equilibrium, 12(1), 34-45.

Latifah, S. W., Jati, A. W., \& Retna, E. (2016). Pengembangan Usaha bagi Mantan TKI di Kecamatan Donomulyo Kabupaten Malang. Jurnal Bisnis Manajemen dan Perbankan, 2(1), 67-80.

Mubarok, F. K., \& Imam, M. K. (2020). Halal Industry in Indonesia; Challenges and Opportunities. Journal of Digital Marketing and Halal Industry, 2(1), 55-64.

Muñoz-Pascual, L., Curado, C., \& Galende, J. (2019). The Triple Bottom Line on Sustainable Product Innovation Performance in SMEs: A Mixed Methods Approach. Sustainability, 11(6), 1689. https://doi.org/10.3390/su11061689

Pîrvu, R., \& Axinte, G. (2012). Return Migration-Reasons, Consequences and Benefits. Annals of the University Petroşani Economics, 12(4), 193-202.

Rachman, M. A., \& Syamsuddin. (2019). Halal Industry in Indonesia: The Role of Sharia Financial Institutions in Driving Industrial and Halal Ecosystem. Al-Iqtishad: Jurnal Ilmu Ekonomi Syariah (Journal of Islamic Economics, 11(1), 35-58. 
Ramakrishna, V. (2019). The Tripple Bottom Line Attemptimg Regulate Corporate Performance and Ensure Sustainbility Development. Dalam Repple Bottom Line of Sustanibility (hlm. 1-45). Bepress.com Envirosolutions Ltd.

Retnowati, D. (2009). Strategi Pengembangan Kelembagaan dan Koperasi Melalui Sistem Demokrasi di Indonesia. Dalam Seminar Nasional Informatika.

Rifa'i, M. N. (2019). Integrasi Pariwisata Halal di Kota Malang. Falah:Jurnal Ekonomi Syariah, 4(2), 194201.

Salehe, M., Luomaba, J., M, M., E, M., \& KJ, M. (2014). Consumer preference on value added product of farmed fish in Lake Victoria Basin Tanzania. Asian Journal of Apllied Science and Engineering, $3(5)$.

Suparmoko. (1999). Ekonomi Sumber Daya Alam dan Lingkungan (2 ed.). BPFE UGM.

Thompson, A., M, P., J, G., \& Strickland, A.J. (2012). Crafting and Executing Strategy. Mc Graw Hill.

Tuazon, D., Corder, G., \& C., M. L., B. (2013). Sustainable Development: A Review of Theoritical Contribution. International Journal Sustainable Future for Human Security, 1(1), 40-48.

Wahyuningtiyas, N., \& Ramadhan, T. S. (2020). The Influence of Online Review Vlogger on Tourism Decisions to The Beach in Improving Halal Tourism Awarenes for Milennial Generation. Jurnal Inovasi Pendidikan Ekonomi, 10(2), 106-117.

Widyastutik, H. M., \& Intan, E. (2010). Faktor-faktor yang mempengaruhi perkembangan Klaster UKM Alas Kaki di Kota Bogor. Jurnal Manajemen\& Agribisnis, 7(1).

Yahya, S., \& ,Goh, W. K. (2002). Managing human resources toward achieving knowledge management. Journal of Knowledge Management, 6(5), 457-468.

Yin, R. K. (2002). Studi Kasus Desain \& Metode. PT Raja Grafindo Persada.

Kristiyana, N., \& Hamidah, C. (2014). Transisi Peran TKI Purna di Ponorogo, dari Buruh menjadi Wirausahawan dan Tuan Tanah. Jurnal Equilibrium, 12(1), 34-45.

Majid, I. A., \& Koe, W.-L. (2012). Sustainable Entrepreneurship (SE): A Revised Model Based on Triple Bottom Line (TBL). International Journal of Academic Research in Business and Social Sciences, 2(6), 293-310. Retrieved from www.hrmars.com/journals

Muqodim, \& Susilo, J. (2013). Tripple Bottom Line Reporting dalam Pelaporan Tahunan Perusahaan Go Public di Indonesia. JAAI, 17(1), 31-42.

Pîrvu, R., \& Axinte, G. (2012). Return Migration-Reasons, Consequences and Benefits. Annals of the University Petroşani, Economics, 12(4), 193-202.

Qeke, S., \& Dubihlela, J. (2018). Influence of Environmental and Social Programs on Dimensionality of Triple Bottom Line of Manufacturing SMEs in South Africa. International Journal of Business and Management Studies, 10(1), 63-79.

Rizal, M., \& Mustapita, A. F. (2017). Analysis of Labor Migration in Malaysia Using The Cost Benefit Analysis (A Case Study in Malang Regrency). JU-ke, 1(2), 1-5.

Sandra, A. Z., \& Kartawijaya, T. M. (2013). Analisis Pengungkapan Triple Bottom Line dan Faktor Yang Mempengaruhi; Lintas Negara Indonesia dan Jepang. Jurnal Vokasi Indonesia, 1(1), 16-34.

Suyudi, M., \& Mat, J. (2016). Fenomena Konservasi LIngkungan dan Pengorbanan Cost atas Pencapaian Optimasi Economic Performance PT Pertamina Sanga Sanga. Jurnal Eksis, 12(1), 3299-3312.

Tuazon, D., Corder, G., \& Mc Lellan, B. C. (2013). Sustainable Development: A Review of Theoritical Contribution. International Journal Sustainable Future for Human Security, 1(1), 40-48. Retrieved from http://www.j-sustain.com

Vadean, F. P., \& Piracha, M. (2009). Circular Migration or Permanent Return: What Determines Different Forms of Migration? Bonn: Institute for the Study of Labor.

Wikipedia. (2018, January Saturday). Triple bottom line - Wikipedia. Retrieved from Wikipedia Web site: https://en.wikipedia.org

Żak, A. (2015). Tripple Bottom Line concept in Theory and Practice. In M. Rojek-Nowosielska (Ed.), Social Responsibility of Organizations Direction Changes (pp. 252-264). Wrocław: Publishing House of Wrocław University of Economics. 


\section{APPENDIX}

Table 1: Strength Analysis

\begin{tabular}{lllll}
\hline No & Item & Weight & Rating & Value \\
\hline 1 & Tourism Area & 0,16 & 21 & 3,36 \\
2 & Natural resources & 0,16 & 17 & 2,72 \\
3 & Village land & 0,16 & 14 & 2,24 \\
4 & Human Resources & 0,16 & 16 & 2,56 \\
5 & Transportation facilities & 0,16 & 14 & 2,24 \\
6 & Government support & 0,16 & 14 & 2,24 \\
\hline & Total & 1,00 & & 15.36 \\
\hline
\end{tabular}

Table 2: Weakness Analysis

\begin{tabular}{lllll}
\hline No & Item & Weight & Rating & Value \\
\hline 1 & The skills of postmigrant workers & 0,2 & 15 & 3,0 \\
2 & The knowledge of postmigrant workers & 0,2 & 16 & 3,2 \\
3 & Motivation of postmigrant workers & 0,2 & 14 & 2,8 \\
4 & Use of Technology for production & 0,2 & 14 & 2,8 \\
5 & Natural resource management & 0,2 & 14 & 2,8 \\
\hline
\end{tabular}

Table 3: Opportunity Analysis

\begin{tabular}{lllll}
\hline No & Item & Weight & Rating & Value \\
\hline 1 & Small competitors & 0,25 & 17 & 4,25 \\
2 & The scarcity of products & 0,25 & 19 & 4,75 \\
3 & Ease of material access & 0,25 & 17 & 4,25 \\
4 & Government Program Support & 0,25 & 14 & 3,5 \\
\hline & Total & & & 16,75 \\
\hline
\end{tabular}

Table 4: Threatness Analysis

\begin{tabular}{lllll}
\hline No & Item & Weight & Rating & Value \\
\hline 1 & Increased Materials Cost & 0,25 & 14 & 3,5 \\
2 & Natural disasters & 0,25 & 14 & 3,5 \\
3 & $\begin{array}{c}\text { Government bureaucracy in taking care of } \\
\text { business license }\end{array}$ & 0,25 & 17 & 4,25 \\
& Infrastructure is not good & 0,25 & 19 & 4,75 \\
\hline & Total & 1,0 & & 16 \\
\hline
\end{tabular}


